\title{
SS-005 生態心理学と文化心理学の邂逅 : 社会文化的現象への応用
}

\author{
企画代表者: 三嶋 博之 (早稲田大学) \\ 企画者: 森直久 (札幌学院大学) \\ 企画者: 河野 哲也 (立教大学) \\ 話題提供者 : ヴァルシナーヤーン（オールボー大学) \\ 話題提供者: 森直久 (札幌学院大学) \\ 指定討論者: 石黒 広昭 (立教大学) \\ 指定討論者 : サトウタツヤ (立命館大学) \\ 司会者：河野 哲也 (立教大学)
}

ギブソン生態心理学においては、近年、社会文化的現象へのアプローチがなされてきているが、この 方面への発展は途上にある。環境（他者も含む）内の情報やアフォーダンスを抽出しながら行為や認知 を調整するという生態心理学の立場からすると、脳内の表象や集団心のような概念を導入することなく、 集合性、文化、記号現象を扱うことが必要である。ラザラスやシュタインタールの民族心理学に始まる 文化心理学も同様の実体化を回避しながら社会文化現象の理論化を進めようとしているが、人間-環境 関係が構成されると考える点で基本的な態度を異にしている。生態心理学と文化心理学が交流する中で、 社会文化現象を扱うより適切な生態心理学アプローチが期待される。社会文化的現象への生態心理学ア プローチを森氏から、アフォーダンス概念を歴史-文化心理学の観点から眺めようとする立場をV Valsiner 氏から話題提供し、石黒氏、サトウ氏のコメントを仰ぐこととする。

\section{ヴァルシナーヤーン (オールボー大学)}

近年アフォーダンス概念を社会文化的現象へと拡張してギブソンの枠組みの理論的間隙を埋めようとの試みがあるが、そ れは知覚/行為の直接性を越え出ることによって可能となろう。記号的媒介の文化心理学は、環境との関係（アフォーダン スを含む）を既存のそして予期される関係に基づきつつ能動的に構築しようとする人間観に始まる。常に新しい意味を含ん だアフォーダンスを構成し続けることで人は更なる心理的、社会的発達に向かう。

\section{森直久 (札幌学院大学)}

物理的には同じ音声として知覚されるにもかかわらず、言葉の意味はしばしば個人によって異なる。これは部分的には、 個人の履歴（歴史性）によって説明されよう。文化心理学であれば歴史性は超越的なものとして考元られようが、生態心理 学は、高次の不変項、すなわちより抽象的な（超越的でなく）情報に訴えるだろう。プロレスファンが引用する人気レスラー の発言を題材にして、歴史性が超越的なのか、抽象的なのかを考えてみたい。 